\title{
Front Matter: Volume 8336
}

, "Front Matter: Volume 8336," Proc. SPIE 8336, Integrated Modeling of Complex Optomechanical Systems, 833601 (7 December 2011); doi: $10.1117 / 12.920466$

SPIE Event: Integrated Modeling of Complex Optomechanical Systems, 2011, SPIE. Kiruna, Sweden 


\section{PROCEEDINGS OF SPIE}

\section{Integrated Modeling of Complex Optomechanical Systems}

\section{Torben Andersen}

Anita Enmark

Editors

15-17 August 2011

Kiruna, Sweden

Organized by

SRT, Division of Space Technology, Luleå University of Technology (Sweden)

Lund Observatory, Lund University (Sweden)

Published by

SPIE

Volume 8336 
The papers included in this volume were part of the technical conference cited on the cover and title page. Papers were selected and subject to review by the editors and conference program committee. Some conference presentations may not be available for publication. The papers published in these proceedings reflect the work and thoughts of the authors and are published herein as submitted. The publisher is not responsible for the validity of the information or for any outcomes resulting from reliance thereon.

Please use the following format to cite material from this book:

Author(s), "Title of Paper," in Integrated Modeling of Complex Optomechanical Systems, edited by Torben Andersen, Anita Enmark, Proceedings of SPIE Vol. 8336 (SPIE, Bellingham, WA, 2011) Article CID Number.

ISSN 0277-786X

ISBN 9780819489937

Published by

SPIE

P.O. Box 10, Bellingham, Washington 98227-0010 USA

Telephone +1 3606763290 (Pacific Time) · Fax +1 3606471445

SPIE.org

Copyright (C) 2011, Society of Photo-Optical Instrumentation Engineers

Copying of material in this book for internal or personal use, or for the internal or personal use of specific clients, beyond the fair use provisions granted by the U.S. Copyright Law is authorized by SPIE subject to payment of copying fees. The Transactional Reporting Service base fee for this volume is $\$ 18.00$ per article (or portion thereof), which should be paid directly to the Copyright Clearance Center (CCC), 222 Rosewood Drive, Danvers, MA 01923. Payment may also be made electronically through CCC Online at copyright.com. Other copying for republication, resale, advertising or promotion, or any form of systematic or multiple reproduction of any material in this book is prohibited except with permission in writing from the publisher. The CCC fee code is $0277-786 \mathrm{X} / 11 / \$ 18.00$.

Printed in the United States of America.

Publication of record for individual papers is online in the SPIE Digital Library.

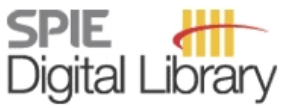

SPIEDigitalLibrary.org

Paper Numbering: Proceedings of SPIE follow an e-First publication model, with papers published first online and then in print and on CD-ROM. Papers are published as they are submitted and meet publication criteria. A unique, consistent, permanent citation identifier (CID) number is assigned to each article at the time of the first publication. Utilization of CIDs allows articles to be fully citable as soon as they are published online, and connects the same identifier to all online, print, and electronic versions of the publication. SPIE uses a six-digit CID article numbering system in which:

- The first four digits correspond to the SPIE volume number.

- The last two digits indicate publication order within the volume using a Base 36 numbering system employing both numerals and letters. These two-number sets start with $00,01,02,03,04$, $05,06,07,08,09,0 A, 0 B \ldots 0 Z$, followed by 10-1Z, 20-2Z, etc.

The CID number appears on each page of the manuscript. The complete citation is used on the first page, and an abbreviated version on subsequent pages. Numbers in the index correspond to the last two digits of the six-digit CID number. 


\section{Contents}

vii Conference Committee

ix Introduction

xi Conference Photo

\section{SESSION 1 INTRODUCTION}

833602 A perspective on modeling and simulation of complex dynamical systems [8336-30]

K. J. Åström, Lund Univ. (Sweden)

\section{SESSION 2 LARGE TELESCOPE PROJECTS: MODELING STATUS I}

833603 Systems modeling in the design and verification of the James Webb Space Telescope [8336-14]

D. M. Muheim, M. T. Menzel, NASA Goddard Space Flight Ctr. (United States)

833604 Opto-mechanical modeling of the Herschel Space Telescope at ESA/ESTEC [8336-19] S. Fransen, D. Doyle, European Space Agency (Netherlands); B. Catanzaro, CFE Services (United States)

\section{SESSION 3 LARGE TELESCOPE PROJECTS: MODELING STATUS II}

833605 Integrated modeling and systems engineering for the Thirty Meter Telescope [8336-37]

G. Z. Angeli, K. Vogiatzis, Thirty Meter Telescope Observatory (United States);

D. MacMynowski, California Institute of Technology (United States); B.-J. Seo, C. Nissly, M. Troy, Jet Propulsion Lab. (United States); M. Cho, National Optical Astronomy Observatory (United States)

833606 E-ELT modeling and simulation toolkits: philosophy and progress status [8336-09] B. Sedghi, M. Müller, H. Bonnet, M. Esselborn, M. Le Louarn, R. Clare, F. Koch, European Southern Observatory (Germany)

\section{SESSION 4 LARGE TELESCOPE PROJECTS: MODELING STATUS III}

833607 Modeling and analysis of ring telescope [8336-16]

Y. Dai, J. Lin, Yunnan Astronomical Observatory (China) 
833608 Pointing stability and image quality of the SOFIA Airborne Telescope during initial science missions [8336-21]

U. Lampater, Univ. of Stuttgart (Germany) and NASA Dryden Flight Research Ctr. (United States); P. Keas, Moog CSA Engineering (United States); R. Brewster, NASA Ames Research Ctr. (United States); T. Herter, Cornell Univ. (United States); J. Wolf, E. Pfüller, M. Wiedemann, Univ. of Stuttgart (Germany) and NASA Ames Research Ctr. (United States); S. Teufel, Univ. of Stuttgart (Germany) and NASA Dryden Flight Research Ctr. (United States); F. Harms, Kayser-Threde GmbH (Germany); H. Jakob, Univ. of Stuttgart (Germany) and NASA Dryden Flight Research Ctr. (United States); H.-P. Röser, Univ. of Stuttgart (Germany)

833609 Simulation of Chinese Giant Solar Telescope [8336-24]

Z. Liu, Z. Jin, Yunnan Astronomical Observatory (China)

SESSION 5 INTEGRATED MODELS I

8336 OA NRCIM integrated opto-mechanical analysis toolset for the Thirty Meter Telescope [8336-01] S. Roberts, National Research Council Canada (Canada)

8336 OB High fidelity optical modeling for the TMT [8336-36]

C. Nissly, B.-J. Seo, M. Troy, Jet Propulsion Lab. (United States) and California Institute of Technology (United States); G. Angeli, Thirty Meter Telescope Observatory (United States); M. Cho, National Optical Astronomy Observatory (United States); B. Ellerbroek, Thirty Meter Telescope Observatory (United States); P. Piatrou, Univ. of California, Irvine (United States); L. C. Roberts, Jr., J. C. Shelton, Jet Propulsion Lab. (United States) and California Institute of Technology (United States); L. Wang, Thirty Meter Telescope Observatory (United States)

8336 OC Aero-thermal modeling framework for TMT [8336-10]

K. Vogiatzis, Thirty Meter Telescope Observatory Corp. (United States)

8336 OD Dynamical simulation of E-ELT segmented primary mirror [8336-07]

B. Sedghi, M. Müller, B. Bauvir, European Southern Observatory (Germany)

\section{SESSION 6 INTEGRATED MODELS II}

8336 OE Optical integrated modeling activities for the James Webb Space Telescope (JWST) [8336-33]

J. M. Howard, NASA Goddard Space Flight Ctr. (United States)

8336 OF Modeling and verification of the diffraction-limited visible light telescope aboard the solar observing satellite HINODE [8336-35]

Y. Katsukawa, Y. Suematsu, S. Tsuneta, National Astronomical Observatory of Japan (Japan); K. Ichimoto, Kwasan and Hida Observatory (Japan); T. Shimizu, ISAS/JAXA (Japan)

8336 OG Performance simulations for the conceptual design of the European Solar Telescope (EST) [8336-06]

L. Cavaller, GRANTECAN S.A. (Spain); M. Collados, Instituto de Astrofísica de Canarias (Spain); J. Castro, GRANTECAN S.A. (Spain) 
$8336 \mathrm{OH}$ The optimization of the opto-mechanical performance of the mirror segments for the E-ELT [8336-28]

J. Nijenhuis, R. Hamelinck, TNO (Netherlands)

$8336 \mathrm{OI}$ The simulation of the local seeing in segments active alignment [8336-17]

S. Yuan, J. Lin, Yunnan Astronomical Observatory (China)

\section{SESSION 7 INTEGRATED MODELS III}

8336 0J Integrated model of the Carlina Telescope [8336-40]

A. Enmark, Luleå Univ. of Technology (Sweden); T. Andersen, M. Owner-Petersen, Lund

Observatory (Sweden); R. Chakraborty, A. Labeyrie, Collège de France (France)

8336 OK ATST enclosure mechanical and thermal models [8336-12]

G. Murga, AEC IDOM (United States); H. Marshall, L. Phelps, AURA (United States); A. Hervás,

I. Larracoechea, AEC IDOM (United States)

$8336 \mathrm{OL}$ Integrated modeling analysis of a novel hexapod and its application in active surface [8336-26]

D. Yang, Nanjing Institute of Astronomical Optics \& Technology (China); L. Zago, Univ. of Applied Sciences of Western Switzerland (Switzerland); H. Li, Nanjing Institute of Astronomical Optics \& Technology (China) and Graduate Univ. of Chinese Academy of Science (China); G. Lambert, Univ. of Applied Sciences of Western Switzerland (Switzerland); G. Zhou, G. Li, Nanjing Institute of Astronomical Optics \& Technology (China)

8336 OM Track creep: experience, modeling efforts, and consequences of work done at the 100 meter Green Bank Telescope [8336-04]

D. Egan, National Radio Astronomy Observatory (United States)

\section{SESSION 8 INTEGRATED MODELS IV}

8336 ON Integrated modeling of a laboratory setup for a large deformable mirror [8336-11]

R. Heimsten, T. Andersen, M. Owner-Petersen, Lund Observatory, Lund Univ. (Sweden);

D. G. MacMynowski, California Institue of Technology (United States)

833600 Local effects on E-ELT global performance: two examples for requirement verification [8336-08]

B. Sedghi, M. Müller, F. Koch, L. Pettazzi, European Southern Observatory (Germany)

8336 OP E-ELT active optics system modeling and performance evaluation [8336-20]

H. Bonnet, M. Esselborn, M. Müller, B. Sedghi, F. Koch, European Southern Observatory (Germany)

\section{SESSION 9 CONTROL SYSTEM RELATED MODELING}

$83360 Q \quad$ Model-based wavefront control for CCAT [8336-31]

D. Redding, J. Z. Lou, A. Kissil, M. Bradford, Jet Propulsion Lab. (United States); S. Padin,

D. Woody, California Institute of Technology (United States) 
8336 OR Control system modeling for the Thirty Meter Telescope primary mirror [8336-02]

D. G. MacMynowski, California Institute of Technology (United States); P. M. Thompson, Systems Technology, Inc (United States); J. C. Shelton, L. C. Roberts, Jr., M. M. Colavita, Jet Propulsion Lab. (United States); M. J. Sirota, Thirty Meter Telescope Project (United States)

8336 OS Modeling of the SOFIA secondary mirror controller [8336-15]

A. Reinacher, Univ. of Stuttgart (Germany) and NASA Dryden Flight Research Ctr. (United States); H.-P. Roeser, Univ. of Stuttgart (Germany)

8336 OT Alignment estimation and control of the James Webb Space Telescope mirrors using decomposition of an influence matrix [8336-32]

S. Shiri, J. M. Howard, D. L. Aronstein, NASA Goddard Space Flight Ctr. (United States)

\section{SESSION 10 THERMAL MODELING}

$8336 \mathrm{OU}$ A dynamic thermal model for design and control of an 800-element open-air radio telescope [8336-13]

M. Bremer, A. Greve, IRAM-Domaine Univ. de Grenoble (France)

8336 OV Thermal modeling of the TMT Telescope [8336-18]

M. Cho, National Optical Astronomy Observatory (United States); A. Corredor, Univ. of Arizona (United States); K. Vogiatzis, G. Angeli, California Institute of Technology (United States)

8336 OW Integration of a thermo-structural analysis with an optical model for PEPSI polarimeter [8336-03]

I. Di Varano, K. G. Strassmeier, I. Ilyin, M. Woche, Leibniz Institut für Astrophysik Potsdam (Germany); H. J. Kaercher, MT Mechatronics (Germany)

8336 0X Athermal design of the optical tube assemblies for the ESO VLT Four Laser Guidestar Facility [8336-27]

R. Henselmans, D. Nijkerk, M. Lemmen, F. Kamphues, TNO (Netherlands)

\section{SESSION 11 SIMULATION TECHNIQUES}

8336 OY Parallel-computing architecture for JWST wavefront-sensing and integrated modeling [8336-38]

J. S. Smith, B. H. Dean, A. Rilee, T. P. Zielinski, NASA Goddard Space Flight Ctr. (United States)

$83360 Z$ The experience of GPU calculations at Lunarc [8336-23]

A. Sjöström, J. Lindemann, Lund Univ. (Sweden); R. Church, Lund Observatory, Lund Univ. (Sweden)

833610 Transitioning a message passing interface wavefront sensor model to a graphics processor environment [8336-25]

M. T. Browne, R. Miceli, National Univ. of Ireland, Galway (Ireland)

Author Index 


\title{
Conference Committee
}

\author{
Conference Chairs \\ Torben Andersen, Lund University (Sweden) \\ Anita Enmark, Luleå University of Technology (Sweden) \\ Program Committee \\ George Angeli, Thirty Meter Telescope Project (United States) \\ Thomas Gustafsson, Luleå University of Technology (Sweden) \\ Mike Lieber, Ball Aerospace \& Technologies Corporation (United \\ States) \\ Danniella Muheim, NASA (United States) \\ David Redding, Jet Propulsion Laboratory (United States) \\ Babak Sedghi, European Southern Observatory (Germany) \\ Session Chairs \\ 1 Introduction \\ Anita Enmark, Luleå University of Technology (Sweden) \\ 2 Large Telescope Projects: Modeling Status I \\ David Redding, Jet Propulsion Laboratory (United States) \\ 3 Large Telescope Projects: Modeling Status II \\ Scott Roberts, National Research Council (Canada) \\ $4 \quad$ Large Telescope Projects: Modeling Status III \\ George Angeli, Thirty Meter Telescope Observatory (United States) \\ 5 Integrated Models I \\ Danniella Muheim, NASA (United States) \\ 6 Integrated Models II \\ Matt Johns, Giant Magellan Telescope Organization (United States) \\ $7 \quad$ Integrated Models III \\ Sebastiaan Fransen, European Space Agency (Netherlands) \\ 8 Integrated Models IV \\ Torben Andersen, Lund University (Sweden)
}


9 Control System Related Modeling

Babak Sedghi, European Southern Observatory (Germany)

10 Thermal Modeling

Doug MacMynowski, Thirty Meter Telescope Observatory (United States)

11 Simulation Techniques

Zhong Liu, Yunnan Astronomical Observatory (China) 


\section{Introduction}

Mathematical modeling and performance simulation are playing an increasing role in large, high-technology projects. There are two reasons; first, projects are now larger than they were before, and the high cost calls for detailed performance prediction before construction. Second, in particular for space-related designs, it is often difficult to test systems under realistic conditions beforehand, and mathematical modeling is then needed to verify in advance that a system will work as planned.

Computers have become much more powerful, permitting calculations that were not possible before. At the same time mathematical tools have been further developed and found acceptance in the community. Particular progress has been made in the fields of structural mechanics, optics and control engineering, where new methods have gained importance over the last few decades. Also, methods for combining optical, structural and control system models into global models have found widespread use. Such combined models are usually called integrated models and were the subject of this symposium.

The objective was to bring together people working in the fields of groundbased optical telescopes, ground-based radio telescopes, and space telescopes. We succeeded in doing so and had 39 interesting presentations and many fruitful discussions during coffee and lunch breaks and social arrangements. We are grateful that so many top ranked specialists found their way to Kiruna and we believe that these proceedings will prove valuable during much future work.

\section{Torben Andersen Anita Enmark}


Downloaded From: https://www.spiedigitallibrary.org/conference-proceedings-of-spie on 26 Apr 2023

Terms of Use: https://www.spiedigitallibrary.org/terms-of-use 


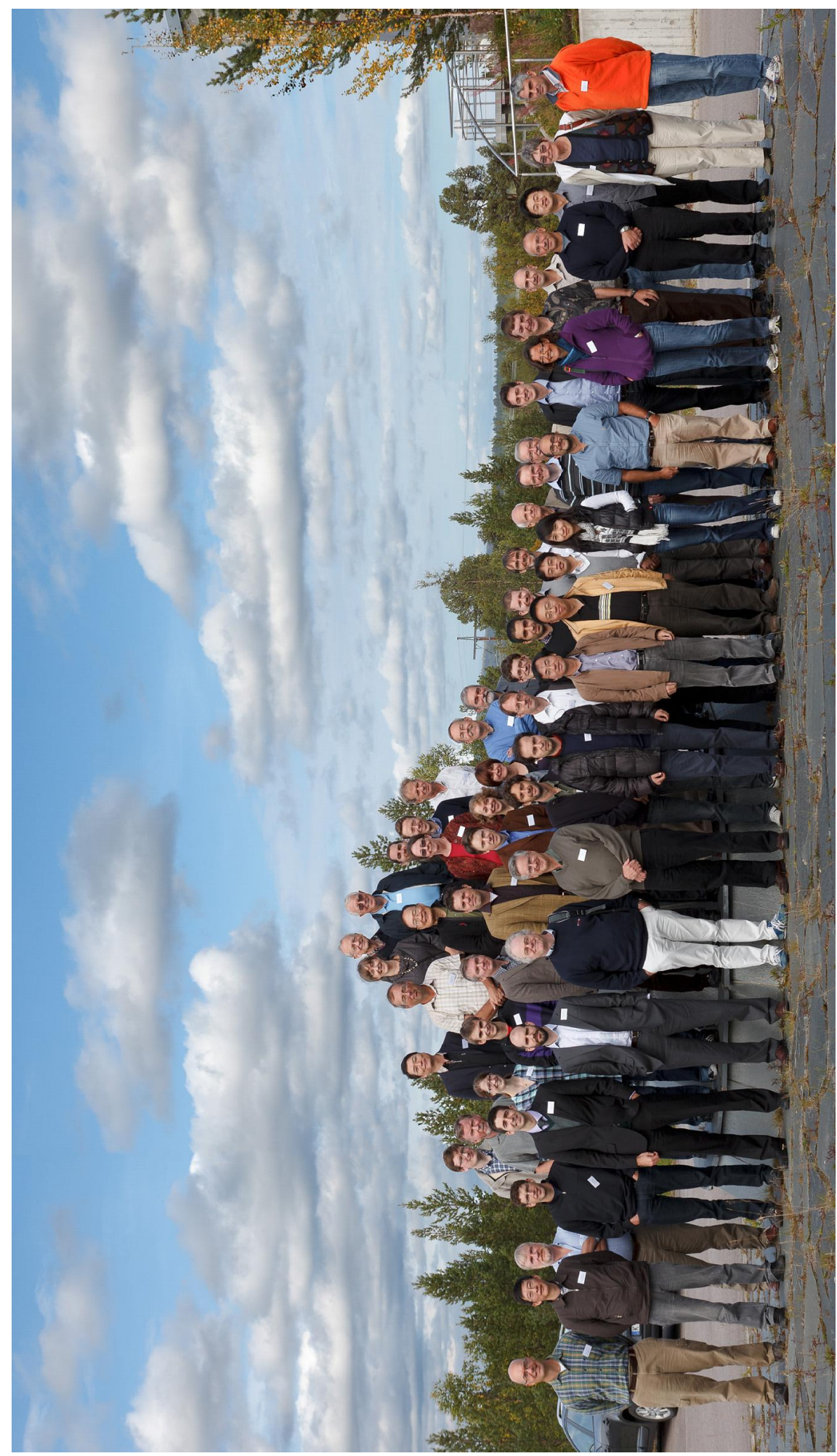




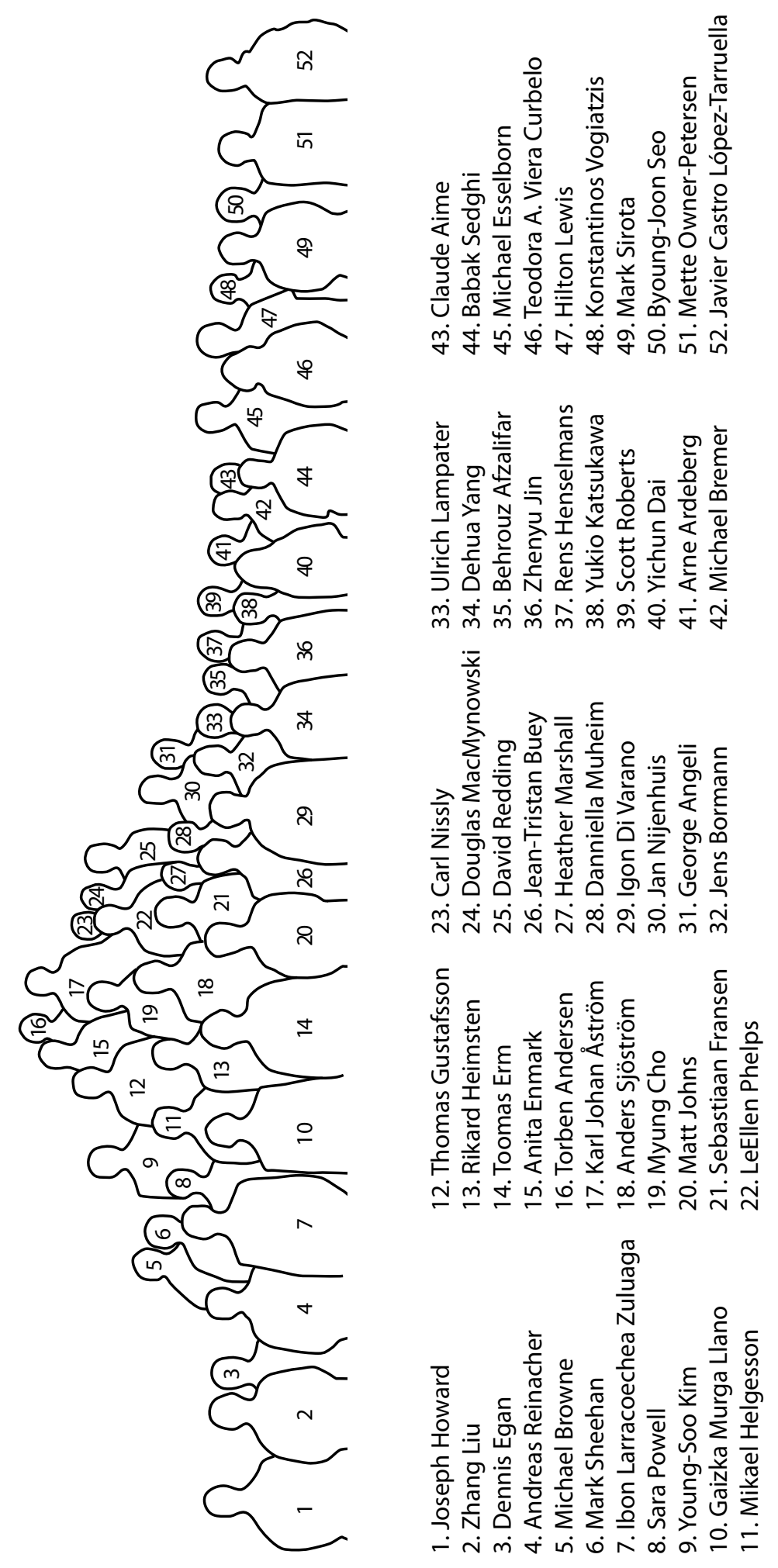

